\title{
Doing mission inclusively
}

\section{Authors:}

Johannes Reimer ${ }^{1,2}$ (D)

Zuze Banda² (D

\section{Affiliations:}

${ }^{1}$ Gesellschaft für Bildung und Forschung in Europa,

Germany and Theologische

Hochschule Ewersbach,

Germany

${ }^{2}$ University of South Africa,

South Africa

\section{Corresponding author:}

Zuze Banda,

bandazj@unisa.ac.za

\section{Dates:}

Received: 29 July 2015

Accepted: 12 Feb. 2016

Published: 24 June 2016

How to cite this article:

Reimer, J. \& Banda Z., 2016,

'Doing mission inclusively',

HTS Teologiese Studies/

Theological Studies 72(1),

a3126. http://dx.doi.

org/10.4102/hts.v72i1.3126

\section{Copyright:}

(C) 2016. The Authors.

Licensee: AOSIS. This work

is licensed under the

Creative Commons

Attribution License.

\section{Read online:}

This article posits that Christians, while being in the world, are not of this world. This duality confronts them with the twofold need to be fully compliant with the demands of their faith and its calling to evangelise this world, on the one hand; and to live fully as fellow citizens of this world, and to cooperate with them in search of solutions for this world's challenges, on the other hand. Lessons are drawn from cultural anthropology theories to underscore dynamic processes of change, that start from non-threatening positions of working together inclusively, thus building trust, and advancing progressively, paving ways for dialogically sharing the Gospel. These developments are at the end argued and justified theologically, and then concluded with pragmatic examples drawn from live ministries born out of the co-author's initiatives.

\section{Introduction}

In his well-written book entitled, How to reach secular people, the American church planter, Hunter III, develops criteria of effective communication with secular people. He states:

Effective communicators do not try to do all the communicating. They know that the faith is more 'caught than taught' that a person's meaningful 'involvement' can do its own communicating, and that involvement helps people to discover the faith for themselves; so they get seekers involved in the fellowship, message, and service of the congregations. Many people come to believe from several months of involvement (Hunter 1992:99-100).

Moreover, Harnish (in Hunter 1992:100), who intensively practices participative evangelism, observes:

I grew up thinking that the sequence was, accept Jesus, then read the Bible, then get into fellowship and serve in the world. But I learned that, usually, it is just the opposite; they get involved first, then they ask the biblical and theological questions, then they move into commitment. (Harnish in Hunter 1992:100)

It is widely accepted in missiological circles that mission requires involvement, contextualisation, and inculturation. Those who share the Gospel cannot reach people without learning their language, rituals, rules, values, and other religious and cultural settings. It is only when we understand the people that we will begin to communicate meaningfully with them in a manner that they may understand what we have in mind. The mission of the church for the people and the church is 'a community for the world' Barth (1962:762ff), or as Dietrich Bonhoeffer (1971:382f) puts it, 'The church is the church only when it exists for others ... The church must share in the secular problems of ordinary human life, not dominating, but helping and serving'. ${ }^{1}$

The challenge in outreach, however, is how to make inroads into a foreign culture. Further still, it is how the church can become a 'church for others', without falling into the helper-syndrome of 'pro-existence' as Sundermeier (1986:62ff) critically observes in his reflection of this Bonhoeffer phrase and its liberal-humanist background. ${ }^{2}$ Too often the 'church for others' falls foul to the fallacy of knowing better regarding what the others need. In this mode, the helper soon dominates those who are in need of help. Sundermeier therefore suggests, instead of talking about a 'church for others', we should speak of the 'church with others' (1986:62ff). It is not pro-existence but coexistence (1986:65) that is required in mission. Similarly, Gourdet (1996:407f) suggests that identification with the people can only be reached through a realistic participation in the life of the people. This requires that we work less for the people but rather with them. If we fail to be close to the people we will be unable to develop proper ways of missionary communication, because we will not be able to learn from and with them (Hesselgrave 1991:46). Learning together with those 1.Translation in Bosch (2011:384)

2.See also Bosch (2011:384).

Note: J. Reimer is Professor Extraordinarius in Missiology at Unisa and President of The Network for Education and Research in Europe (GBFE). Z.J. Banda is Senior Lecturer and HoD in Department of Christian Spirituality, Church History and Missiology. 
whom we seek to evangelise is a crucial precondition for any meaningful evangelism (Loewen 1977:36). ${ }^{3}$ Evangelisation requires an open space in which all participants feel welcome to share their part of the story without limitations. Such an open space presupposes a culture of welcome. ${ }^{4}$

A question may however be posed as to whether participative evangelism and mission are theologically adequate. Stated otherwise, we need to consider whether the mission of a 'church with others', is biblically speaking, an option. We need to question, whether it is not rather one of those neoliberal ideas of a Western democratistic culture. Having considered that, we need then to investigate how to develop an inclusive praxis of mission without compromising our exclusive faith. This is a research question that is by all means not an easy one to answer as the debate around the common ground theology ${ }^{5}$ shows. These and other similar questions will guide our unfolding discussion.

\section{Creative tension: In the world but not of the world}

In addressing this subtopic, there are some philosophical observations to ponder. As a starting point, let us compare the modern Western thinking with the Hebrew thinking as contained in the Old and the New Testament. For most people, knowledge starts and ends with a dividing line. Such a simple line sets the parameters of past and future, now and then, us and them, thesis and antithesis, and so on. Such dichotomies may help clarify certain identities, but also open the discussion on differences. As Christians we have traditionally followed the same pattern. ${ }^{6}$

For many years this has also been the classic approach in missiology. Yoder's famous dictum, 'Where there is no world there can be no mission' (Yoder in Reimer 2009:2007) stands as an example. He argues that we create the need for evangelism and mission by drawing the line between us in the church and those in the world; the saved and the unsaved. From this stance, we then listen to God's commission, which is, calling us to disciple the unsaved. As soon as we cross the dividing line we are in mission, as crossing frontiers.

There are views that may argue this as biblical. They may posit that God initially paraded these dualities in the beginnings of life on earth by dividing water from water, light from darkness, animals from humans (Gn. 1:1ff). Based on this surmise they may further rhetorically argue, 'Does God not separate the chosen from the not-chosen? Has he not elected Abraham and with him Israel from the rest of the

3.See also Gourdet (1996:407); Hiebert 1985:81f.

4.See more about the concept of participation in a culture of welcome in Reime (2013a:140ff).

5.With the term common ground theology (CGT) we mark those attempts radically to contextualise the Gospel into religious frames of reference which would allow the non-Christian religion to determine the outward signs and structures of faith. The non-Christian religion to determine the outward signs and structures of faith. The adherents of CGT will refer to themselves then as Jesus Muslims or Jesus Hindus and Reimer (2012:211-236) and Tennent (2006:101-115).

6.See in this regard Hiebert (2006:196-220) discussion of Western Images of Others and Otherness. nations?' Further still, they may claim, 'In the New Testament, is there not a clear call to urge the chosen people out of the world and to separate themselves into the new social and cultural reality called church?'7

There are no simplistic 'Yes' and ' $\mathrm{No}^{\prime}$ answers to these questions. At a first glance, there is a 'Yes' probability. The Bible teaches about divisions. Jesus himself warned his disciples about divisions that even divide families into friends and enemies. God's word alone divides right from wrong. Digging deeper, however, we soon discover a general inclusiveness of God's dividers. The fact that God separated light from darkness stands to reason that there cannot be light without darkness. In fact, day and night are necessarily two poles of the same reality of life. It is also true that God chose some people from the midst of others but, as in the case of Abraham; he did not select him from the nations for the sake of separation, but rather with a view to be a blessing to all the nations. ${ }^{8}$ Again in the New Testament, Jesus sends his disciples to all nations of the world to make them disciples, but not to withdraw them from the world, but to transform them in the midst of the world. ${ }^{9}$ Whatever God divides, he does so to create wholeness, to heal brokenness, to restore the original image. Hiebert (2006:) states thus:

The scripture leads us to a startling conclusion: On the surface we are males and females. blacks, browns and whites, rich and poor, old and young, but beneath this we are one humanity. Our oneness of humanity is declared in the creation account (Gn. 1:26) and affirmed by the universalism implicit in the Old Testament (Ps. 148:11-13; Is.. 45:22; Mi. 4:1-2). The nations are waiting for Yahwe (Is. 51:5). His glory will be revealed to all of them (Is. 4:5). His servant is the light to the Gentiles (Is. 49:6) and they will worship in God's temple in Jerusalem (Ps. 96:9). (p. 29)

It is biblically a given that humans have sinned against God and against one another. Sin has brought divisions and alienation into the world. ${ }^{10}$ But in Christ humanity and creation is being restored into the ultimate oneness. ${ }^{11}$

As a matter of fact, God clearly identifies matters. He reveals sin and identifies righteousness. He does so to set a process of restoration in motion. His dividers are never a simple line, but rather a cycle with two or even more poles interconnecting life as a whole. Such dividers do not simplify matters. Life, culture, community are neither black or white, nor right or wrong. Life instead is colourful, multidimensional, much more complicated than we sometimes imagine. God's image of restored life is a rainbow, and not just the opposite of darkness. With God, mission is not just a bridge crossing frontiers from the right to the wrong and vice versa; rather, it can be perceived as a cycle - a process, a moving together of poles that are divided - that are achieved by his presence in the world. This intriguing reality becomes clear when we

7.2 Corinthians $6: 17$ 'Therefore come out from them and be separate', says the Lord. Cf. Matthew 28,18ff. (Ac. 2:40).

8.Genesis 12:1-3.

9.Matthew 28:18-20 and John 17:15.

10.Genesis $3: 12,16 ;$. 4:8,23;11:9

11.Philippians 2:11; 1 Corinthians $15: 28$ and 2 Corinthians 5:18-19. 
answer such questions as, 'Can there be humans, regardless of how wrong they may live and how bad and ungodly their lifestyle might be, that God has not made?' The answer clearly indicates God's unquestionable presence throughout creation and among humans. This presence cannot be denied even among those who live a rebellious life.

We want to illustrate this argument further by using the example of world religions. As previously indicated, in the past, drawing a dividing line was very simple. We drew a clear line between Christianity, as only right religion, and others, the non-Christian religions. Kraemer (2009:101ff), for instance, strictly declared all non-Christian religions as demonic. ${ }^{12}$ Today we understand that such a view is oversimplified. We thus hold a view with the German missiologist, Beyerhaus (1969:100-104), a more comprehensive, three-polar view on religion, which rediscovers God's presence in other faiths, human creativity and, of course, in demonic deception. In the first instance, all people are in search for an explanation to the unknown, and desire to receive answers to their questions about the transcendental and to experience even the greatness of the creator. This view suggests that there are traces of God in all world religions. ${ }^{13}$ Beyerhaus (1969:100-104) calls this the theonom principle. Others have preferably used the term general revelation.

In the second instance, Beyerhaus argues that humans have developed their own religious ideas to cope with the unknown. They have given names to phenomena; designed religious theories; and established rites, rituals, moral values, and ethical principles. Religion, Sundermeier (1999:27) states, is always 'a joint answer of people to the transcendental experience in rite and ethic'. And, as with all human inventions, such an answer is never absolute, never totally wrong or totally right. It is contextual, preliminary, and subjective.

In the third instance, Beyerhaus (1969:100-104) says religions are demonically influenced, deceived, and corrupted. Satan will always try to mislead humans and estrange them from God. We may conclude therefore that religions are complex realities. There can never be a simple dividing line of wrong and right to the phenomena, not to even mention their adherents. It may not be wise to deny God's presence among peoples of other religions, nor to eliminate God's influence or involvement in creative human thinking. But it is our epistemological position that we do not accept demonic activity as Divine inspired. In light of Beyerhaus' three-polar view on religions, our position is that which distinguishes, that which is critical and at the same time, that is open to discern the unexpected presence of the Most High in the midst of even a non-biblical religion. Hence we view mission as a journey to and with the people, following God's presence among them in constant battle with the enemy. God's general presence in the world leads us to consider inclusiveness as a vital category of missional praxis.

\section{Change requires inclusiveness - Insights from cultural anthropology}

In this section we wish to extend the debate in a related discipline of cultural anthropology in light of our mission today. As Christians we are called to go and disciple the ethne, that is. nations (Mt. 28:18-20). The Greek term ethnos stands for a socio-political space. The best translation for this debate is simply, culture - understood as 'a way of life of a given people' or 'design for living', as Käser (1997:37) suggests. To disciple nations, according to the teachings of Jesus, means to transform the socio-political reality of the ethnos. To do this, we have to understand culture structurally. Kane notes thus, 'Understanding the culture can spell the difference between success and failure in introducing new ideas or methods ... the missionary ... should also have all the knowledge that is available about the nature of human society and culture before he begins to administer new ideas, which constitute the medicine of social change' (Kane 1986:64). ${ }^{14}$ Teague (1996:166), in his very inspiring book on the correlation between culture and mission, underlines the importance of cultural understanding as 'essential to church growth'.

Culture as 'a Way of living' is, according to cultural anthropology, multi-dimensional (Ferraro 1998:18; Dahl 2001:4, among others). We agree with Ferraro (1998:18) in dividing the cultural space into four levels, namely, (1) things we have, or the material culture; (2) things we do, or the social culture; (3) things we think, or the cognitive culture and lastly (4) things we believe, or the religious culture. We could also speak of religion, worldview, social set of values, and material objectivation and diagrammatically represent it thus (Figure 1).

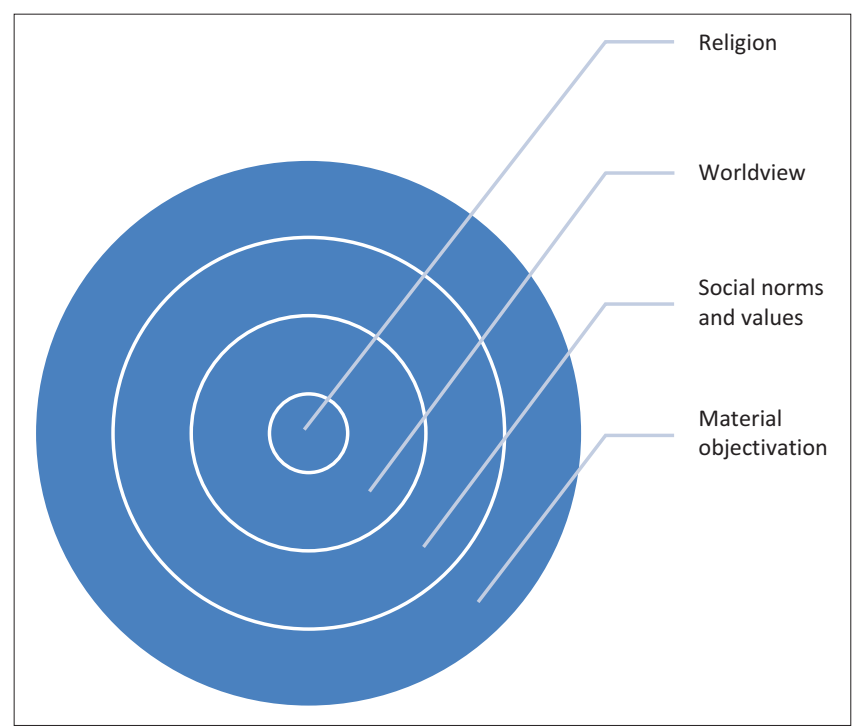

Source: Designed by J. Reimer

FIGURE 1: Cultural dimensions.

14.See also Teague (1996:159). 
According to this anthropological research, what we believe informs our thinking, what we think informs our behaviour, and what we do informs our material status. We have what we do, we do what we think, and we think what we believe. In our chart the power of influence runs from the centre to the periphery. This is why it is so important to change the faith of the people. Well considered beliefs will translate into proper worldviews and determine right behaviour and physical involvement. Hence, renewal, says the apostle Paul, requires the change of mind, and subsequently breeds actions that are agreeable to God's ministry. ${ }^{15}$

The challenge is how this can be achieved, that is, what would be the approach to reach the minds and the belief systems of the people? In such a query, insights from cultural anthropology are very helpful. Some anthropological studies show that cultural change starts from the periphery and works itself to the centre (cf. Ferraro 1998:18ff). There are reasons that influence centripetal direction. One of the factors is that change poses a challenge. To bring about change we have first to win trust with the people. But trust does not necessarily develop through debates and discussions. It is when people work together for the common good, when they talk and discuss their common needs, in their individual and community matters, that they develop trust. It is only when basic trust is established that change does become possible; because change will always challenge your traditional thinking and beliefs. Debates and battles over right or wrong, risk, and potential failure are unavoidable. Most change initiatives lose their potential and dynamics right at this point.

These dynamics are not much different in the area of missions. Mayers (1981:32f) speaks of the 'Question of Prior Trust' (QPT) as the basic precondition for any communication of the Gospel. He says people will not listen to us and will obviously not agree to change their lifestyle, unless they trust us. He further states that trust is not won by engaging in a religious debate, but by involving ourselves in acts of community transformation, working side by side with the people. In other words, living and working with the people in developing a common space of life, discussing felt needs, and searching for ways of solving them, creates ties of trust and a togetherness that holds strong. These will essentially withstand times of debate; of stress; and of the questioning of traditional systems, worldviews, and of beliefs. Our concyclic diagram tries to represent this argument (Figure 2).

\section{Mission requires obedience to the call of God - Insights from theology}

The theory of change as it is expressed in terms of cultural anthropology works basically inclusively (Reimer 2009). Only when you stay with the people, work alongside the people, and dialogue and debate with them will you be able to introduce change.

This in cultural anthropology is called a theory of intercultural communication. Christian mission, however, drives a similar 15.Romans $12: 1-2$.

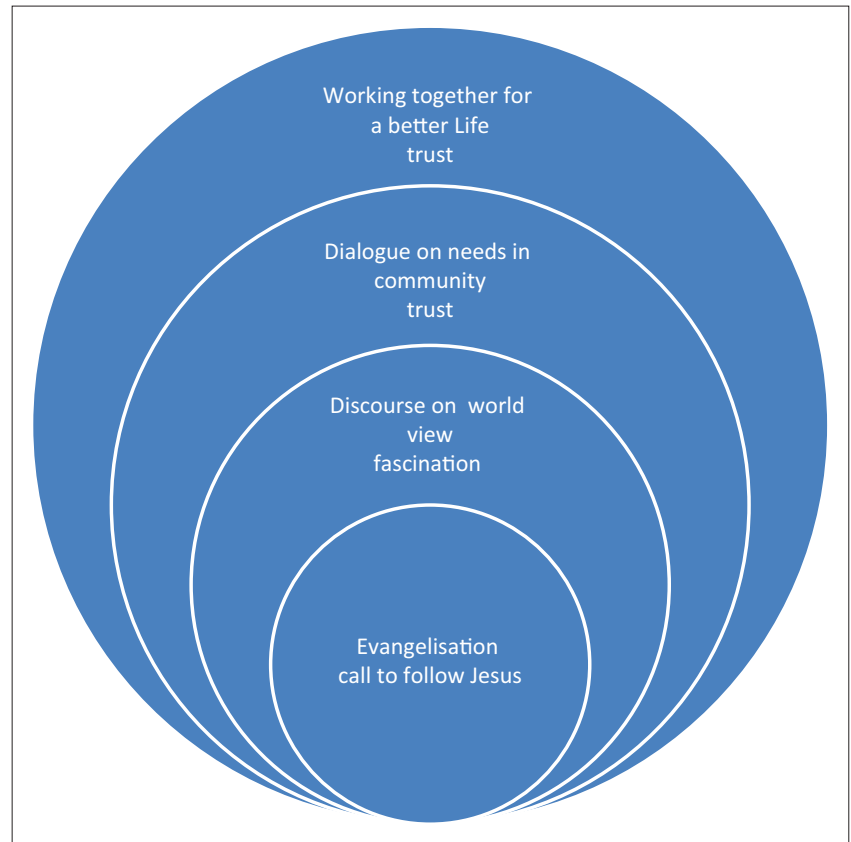

Source: Designed by J. Reimer

FIGURE 2: Process of spiritual transformation.

concept on biblical grounds. It is not enough to claim working with non-Christians, on the ground of what cultural anthropology teaches, as a trust-building venture. A sceptical one may ask whether in the Bible such a notion that encourages Christians to work together with sinners in order to set them free from their bondages does exist. To state in terms of our earlier assertion, whether there is any biblical evidence for a mission-with-others?

In attempting a response, the answer is twofold: (1) we have to consider the lasting validity of the cultural mandate given to all humanity and (2) we have to orientate ourselves on Jesus, the prime source and agent of mission and evangelism.

Firstly, we have earlier suggested an approach that starts mission first by engaging in material and social transformation of a community with the people of the very community. By using tools of community development we have argued for establishing trust with the people that might lead to a deeper level of mission and evangelism. This is a mandate that is grounded on doing things together in an original so-called cultural mandate. ${ }^{16,17}$ In this text God commissions humans to cultivate the land and rule over the earth. This commission has never been withdrawn. Peters (1972:167) states: 'It is man's ${ }^{18}$ responsibility to build a wholesome culture in which man can live as a true human being according to the moral order and creative purposes of God'. Therefore it is still valid for all the people. Some of the remarkable evidences for this are found in the cultures and societies that are centred on human philosophy and development. From personal experiences, one realised, for instance, that some Buddhist

16.Genesis 1:27.

17.The term has been broadly discussed by George W. Peters (1972:166f).

18.For 'man' read 'humanbeing or humanity'. 
Japanese may not have known Jesus yet, but they understand the validity of culture and meaningful societal structures. Some of the most impressive cultural achievements are found in Confucian China. Therefore, religious orientation has not prevented humans from being culturally active and progressive. The apostle Paul says, 'All authorities are given by God to the best' (Rm. 13:1). We work together with the people for the betterment of life because this is clearly the will of God; and his will is expressed in his cultural mandate. All humans are subject to this mandate, regardless of whether they follow Jesus or not. It is not only possible to work together with others, as on material and social issues even as in community development, but it is also our duty.

Secondly, we should orientate our mission on Jesus Christ. This is evident in the Gospels where we will draw a few examples to illustrate this point. His life began with a surprise. It was not the spiritual leaders of Israel, but rather the Gentile magicians from the East who were the first to notice his divine birth. Later in ministry, he, the One who was sent to the lost sheep of the God-chosen nation, avoided connection with the religious elite; but instead called fishermen to join his core ministry, mingled with tax collectors, and even less-than-perfect women to become his disciples. The religious elite observed his ways and how he engaged with communities. They blamed him for eating and drinking with sinners. There his willingness to discover the potential of a faith community goes far beyond Israel. He praised a Roman soldier for his faith. He used a Samaritan as an example for love and care for the needy. In fact, the expression 'Good Samaritan' has become a basic term for compassion. Jesus engaged in a conversation with a prostitute woman, and out of her testimony, the whole Samaritan city of Sichar ran to see him. He commanded his disciples to feed a crowd of 5000 men, knowing that the only food, the five loaves of bread and two fish would be found with a little boy who did not even belong to his followers and was a part of the very crowd the disciples were commanded to feed. Jesus commanded his disciples to bring to him what the community had to offer. The message of these stories clearly points to the reality of mutuality and interdependence. In mission-with-others subjects of mission do not rely on what they have or can offer only, rather, work with those to whom they are sent. ${ }^{19}$

The centrality of Christ can also be established in apostolic activities. The apostle Peter was in the inception stage of the Church to go to the house of Cornelius, a Roman officer. God had been working with Cornelius in his own way and Peter was then asked to lead him to Christ. Peter, the Jew, had to be convinced to do this by a special vision of unclean animals which God commanded him to eat. The justification for the act was, whatever God has made clean, is clean..$^{20}$ There is no question about Jesus' approach regarding 'the other'. His premise was that of not avoiding working with sinners and

19.References: Magicians (Magi) (Mt.2:1-2); Guest of sinners (Lk. 19:7); Good Samaritans (Lk. 10:25-37); Prostitute woman (Jn. 4:1ff); little boy (Mk. 6:35-44).

20.Acts 10:1-30. the non-Jews. His behaviour subsequently is to encourage his followers also to do the same. Christians are sent as he was sent by his Father. ${ }^{21}$ There is obviously a clear biblical justification for a church mission with the people.

Nevertheless, there is also a clear warning. The apostle Paul warns his followers not to put their necks under a common yoke with unbelievers. ${ }^{22}$ Could this be construed as meaning that the apostle prohibited any collaboration of Christians with non-Christians in matters of common good? On the contrary, the passage does not refer to any social involvement, but rather to those actions compromising righteousness, falling into iniquity, or lawlessness. ${ }^{23}$ Apostle Paul warned against compromising the integrity of faith (cf. Hughes 1962:246; Martin 1986:197). For our context, the warning is clear, namely, the church being in the world may not compromise her status of not being of the world..$^{24}$ The church in all her weakness is still a 'holy people', ${ }^{25}$ an alternative community, God's prophetic voice in the world, a sign of the kingdom of God.

Being both in the world with the people and at the same time not of the world, different from the people, creates tension. This is, according to Bosch (2011:390f), the normal condition of a missional church in the world of rebellion, injustice, and disbelief. So the church is invited to continually and critically judge its statuses of what-to-be, where-to-be, and what-to-do.

\section{Men and women of peace}

As Christians we are invited to follow God in His entire mission on earth. Wherever He is, so should we be, also. To discover him among the nations means we should find the right point of departure and connection for our own mission. We should discover those men and women God is working with already. Watson (2011) calls these people, men and women of peace. They are God's entry keys to communities. Connecting with them will open doors for us for effective missional ministries. They know their own people. They see and experience their needs and engage for the better. They sense injustice and some even offer their lives fighting for justice and transformation. They might have not come to know Jesus yet, but God knows them and prepares them for a ministry of his kingdom. We can do well to join hands with them in a community development. We can together work for the betterment of life around us. We can learn to trust each other by establishing a working convivential ${ }^{26}$ space.

Our togetherness with men and women of peace may not, however, downplay the ethical and spiritual differences

22.See 2 Corinthians 6:14-18. Cf. v.14: 'Be not unequally yoked with unbelievers: for what fellowship have righteousness and iniquity? Or what communion has light with darkness?'

23.See in this regard the discussion of the narrative in Barnett (1997:344-355); Hughes (1962:244-248) and Martin (1986:190-200).

24.John 17:16.

25.1 Peter 2:9-10

26.'conviventia' Latin for 'living and working together.
} 
among us. On the contrary, it can encourage us to talk them through, to debate, and even engage in an ongoing discourse for the truth of the Gospel. Friends and partners in social and community development become critical dialogue partners, striving for an appropriate change of mind and heart. As Christians we should always stay obedient to the missionary call of Jesus, of making disciples for him. How we do that is critically important. This introduces us to the next discussion of a praxis of inclusive mission.

\section{Towards a praxis of inclusive mission}

The mission of a church with others is both inclusive and exclusive. Following the change pattern described to us above, by cultural anthropology, our approach should be inclusive in our involvement on the material and personal levels of society and culture. We can then become critical and prophetic on the cognitive worldview level, and we can then also lovingly evangelise in spiritual and religious matters. It is our understanding that such comprehensive mission does not take shape overnight. It requires time, trust-building, common understanding, and an atmosphere of dialogue. Mission here is in a way, a developmental process of four different stages:

- Firstly, we begin with service, joining in with other social players in a given community to work for the better of that community.

- Secondly, we engage in dialogue with those who serve and those we serve, on issues relevant to the community.

- Thirdly, we expose ourselves to questions about our faith and life, as we engage others in love and humility.

- Fourthly, we do not hesitate to explain the Gospel as soon as we are asked exactly for that. This then creates an opportunity to call people to follow Jesus, if they understand and are ready to be challenged accordingly.

These four phases of mission and evangelism do not always necessarily follow a linear and chronological order. The phenomenon can rather be described as a cycle that allows for a back and forth movement while we advance towards the goal of God's mission in the world - as we disciple the social reality of people. In this regard we speak about societytransformative evangelism and mission. ${ }^{27}$ It requires presence, service, dialogue, discourse, and proclamation. We represent this in the following model (Figure 3).

Therefore, regarding all these levels of involvement, Hiebert (2009:179) maintains that Christian mission should place itself in 'between the Gospel and the world', becoming what he calls 'mission as mediation' (2009:179). In fact, mediation is at the heart of all Christian missions, a core competence of the church that is involved in God's mission to the world. ${ }^{28}$ Serving people in joint community development projects, Christians should model to the not-yet-believers how to act as followers of Christ, by feeding their imagination with the 27.For further reading cf. Reimer (2013b).

28.For detailed discussion, see Reimer (2011:19-35).

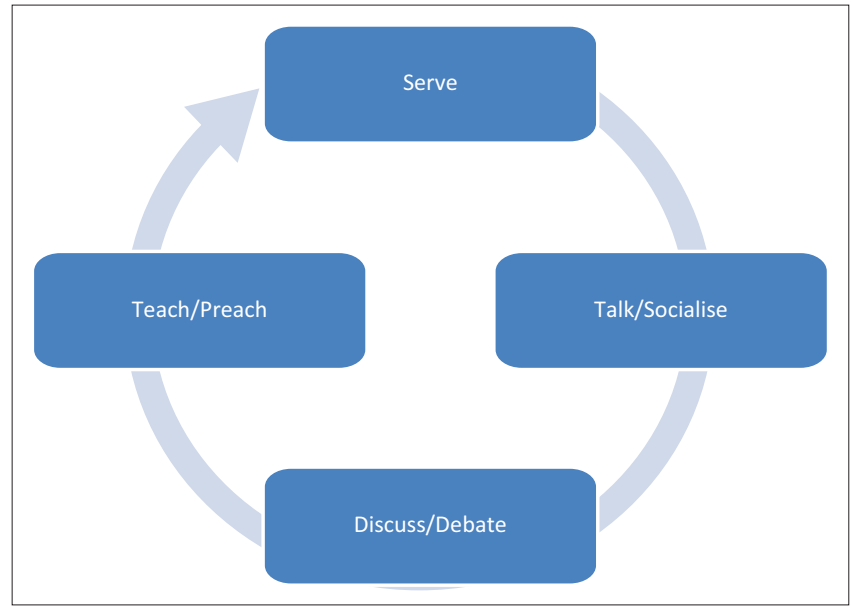

Source: Designed by J. Reimer

FIGURE 3: Cycle of society-transformative mission.

significance of the Gospel for our daily life. In this way service becomes a meditative process between the person and the Gospel. Consequently, the encountered people may start asking questions, and then involve the servants of God in dialogue and discourse on issues they find pertinent. Thus, the Gospel-driven-answer might encourage further a process that leads to a spiritual decision as of a natural act.

To prove the validity of what we have said so far, we will draw examples from projects we have identified in order to underscore the praxis of society transformative mission. The project is called the Christian Employment Agency. ${ }^{29}$ It was started several years ago in a small German town, called Brüchermühle, to help unemployed people earn a living. From its inception the project operated inclusively, inviting everybody in the town to join hands in it. The success of the project has produced amazing results. It has seen how men and women found employment, and the livelihood of their families improved. Over a time many of the clients of this project and their families decided to join the church and follow Jesus. ${ }^{30}$ Similar other projects of transformative mission have been encouraged in a number of German cities. The results have been similar. ${ }^{31}$

There are similar projects on the African soil that we also present as examples. For instance, a project that is within the nature of the above-mentioned model is the 'Earth and Faithkeeping', an initiative of the Research Institute of Theology and Religion at the University of South Africa. In his appraisal of this project, Olivier (2005:1) tells that it was 'the use of basic belief-systems as vehicles to cause a change towards an environmentally more sensitive lifestyle'. Banda (2010:180) remarks about this initiative by saying, 'It is also a multi-faith endeavour because it accommodates African Traditional, Baha'i, Buddhist, Christian, Hindu, Islamic and Jewish perspectives of environmental care'. Another project with an inclusive social transformative sentiment includes 29.The author, Reimer, is personally involved in this project.

30.The work has been studied by Martin Schulten, see Schulten (2012).

31.See some of the projects in Faix (2014). 
the Zirrcon (Zimbabwe Institute of Religious Research and Ecological Conservation), an initiative of a now retired professor of missiology at the University of South Africa, Inus Daneel (Charamba, Chiwara \& Mfanyane 1997, in Cuthbertson et al. 2003:43). ${ }^{32}$ The project's main thrust is tree planting and replenishing of ecosystems that are under threat in Zimbabwe.

A comprehensive transformative approach to mission and church planting as mission with others, using basic structures of joint community development remains a viable and sustainable option in complex multifaith contexts.

\section{Conclusion}

We have tried to demonstrate that involvement of Christians in their local communities in search of solutions to their felt needs introduces an unorthodox approach to evangelism and mission. It is inclusive. This approach guarantees trust whereby permission to debate and to confront the other with the Gospel of Jesus Christ is made possible. This was also understood as mission-with-others that creates an opportunity for effective contextualisation and inculturation of the Gospel. We have seen how this concurs with numerous examples cited from the Bible. Not only are these scripturally tenable but they could be reproduced and modelled on pragmatic examples that have been born of the initiatives and labours of the co-author (Reimer) in Germany and other role players.

\section{Acknowledgements Competing interests}

The authors declare that they have no financial or personal relationships which may have inappropriately influenced them in writing this article.

\section{Authors' contributions}

J.R. made substantive contributions to the topic and argumentation and Z.B. made complementary contributions, by introducing African contextuality to the topic, doing language editing, and formatting and preparing the document for publishing.

\section{References}

Banda, Z.J., 2010, 'African Renaissance and missiology: A perspective from mission praxis', Unpublished doctoral thesis, UNISA.

Barnett, P., 1997, The second epistle to the Corinthians. The New International Commentary on the New Testament, Eerdmans, Grand Rapids, MI.

Barth, K., 1962, Church Dogmatics IV/3, T.\&T. Clark, Edinburgh.

Beyerhaus, P., 1969, 'Zur Theologie der Religionen im Protestantismus', Kerygma und Dogma 15(1969), 100-104.

32.For more African based relevant projects and concepts, see Banda (2010:179-185)
Bonhoeffer, D., 1971, Letters and papers from Prison, The enlarged edition, SCM Press, London.

Bosch, D.J., 2011, Transforming mission. Paradigm shifts in theology of mission, Orbis, Maryknoll, NY.

Charamba, G., Chiwara, T. \& Mfanyane, F., 1997, Muchakata and the war of the trees, in Frontiers of African Christianity: Essays in honour of Inus Daneel, edited by Cuthbertson, G., Pretorius, H. \& Robert, D., 2003, UNISA Press, Pretoria.

Dahl, S., 2001, 'Einführung in die Interkulturelle Kommunikation', viewed 19 June 2013, from http://www.intercultural-network.de/einführung

Faix, T., Mueller, T. \& Bosner, V., 2014, Tat. Ort. Glaube. Transformationsstudien, vol. 6, Francke, Marburg.

Ferraro, G., 1998, Cultural anthropology: An applied perspective, Wadsworth, Independence, MO.

Gourdet, S., 1996, 'Identification in intercultural communication', Missionalia 24(3), 399-409.

Hallencreutz, C.F., 1966, Kraemer towards Tambaram. A study in Hendrik Kraemer's missionary approach, Almquist \& Wiksells, Uppsala.

Hesselgrave, D.J., 1991, Communicating Christ cross-culturally. An introduction to missionary communication, Zondervan, Grand Rapids, MI.

Hiebert, P.G., 1985, Anthropological insights for missionaries, Baker, Grand Rapids, MI.

Hiebert, P.G., 2006, 'Are We Our Others Keeper's', in C.V. Matthew (ed.), Integral mission. The way forward, pp. 196-220, Christava Sahitya Samithi, Tirruvala.

Hiebert, P.G., 2009, The Gospel in human contexts. Anthropological explorations for contemporary missions, Baker, Grand Rapids, MI.

Hughes, P.E., 1962, The second epistle to the Corinthians. The New International Commentary on the New Testament, Eerdmans, Grand Rapids, MI.

Hunter, G.G., III., 1992, How to reach secular people, Abingdon Press, Nashville, TN.

Kane, H., 1986, Wanted: World Christians, Baker, Grand Rapids, MI.

Käser, L., 1997, Fremde Kulturen. Eine Einführung in die Ethnologie, VLM, Bad Liebenzell.

Kraemer, H., 2009, The Christian message in a non-Christian World, Reprint in Missiological Classics Series Vol. 6, ed. by Siga Arles, general editor. Center for Contemporary Christianity, Bangalore.

Loewen, J.A., 1977, Culture and human values: Christian interpretation in anthropological perspective, WCL, Pasadena, CA.

Martin, R.P., 1986, 2 Corinthians. Word Biblical Commentary, vol. 40, Word Books, Waco, TX.

Mayers, M.K., 1981, Christianity confronts culture, Zondervan, Grand Rapids, MI.

Olivier, D., 2005, Faith \& Earthkeeping? Faith and Earthkeeping No.1 (June), 1-2.

Peters, G.W., 1972, A biblical theology of missions, Moody Press, Chicago, IL.

Reimer, J., 2009, Die Welt umarmen. Theologie des gesellschaftsrelevanten Gemeindebaus. Transformationsstudien Bd. 1, Francke, Marburg.

Reimer, J., 2011, 'Der Dienst der Versöhnung - bei der Kernkompetenz ansetzen. Zur Korrelation von Gemeinwesenmediation und multikulturellem Gemeindebau' Theologisches Gespräch Heft 1(2011), 19-35.

Reimer, J., 2012, 'Common Ground oder doch nur Anknüpfungspunkt? Zur Frage der hochspektralen Kontextualisierung am Beispiel des Islam', in T. Faix, H. Georg Wünch \& E. Meier (eds.), Theologie im Kontext von Biographie und Weltbild. GBFE Jahrbuch 2011-2012, pp. 211-236, Francke, Marburg.

Reimer, J., 2013a, Hereinspaziert. Willkommenskultur und Evangelisation, Neufeld, Schwarzenfeld.

Reimer, J., 2013b, Leben. Rufen. Verändern. Chancen und Herausforderungen gesellschaftstransformativer Evangelisation heute. Transformationsstudien Bd. 5 , gesellschaftstransformativer
Francke Verlag, Marburg.

Schulten, M., 2012, 'Gesellschaftstransformativer Gemeindebau. Am Beispiel der Evangelischen Freien Gemeinde Brüchermühle und deren Sozialarbeit für Hartkernarbeitslose in der Christlichen Beschäftigungsgesellschaft'. Unpublished Hartkernarbeitslose in der Christlic
MTh dissertation. UNISA, Pretoria.

Sundermeier, T., 1986, 'Konvivenz als Grundstruktur ökumenischer Existenz heute', Ökumenische Existenz Heute 1, pp. 49-100.

Sundermeier, T., 1999, Was ist Religion? Religionswissenschaft im theologischen Kontext, Gütersloher Verlagshaus, Gütersloh.

Teague, D., 1996, Culture - the Missing Link in Missions, OMF Literature, Manila.

Tennent, T.C., 2006, 'Followers of Jesus (Isa) in Islamic Mosques: A closer examination of C-5 'high spectrum' contextualization,' International Journal of Frontier Missions 23(3), 101-115.

Watson, D., 2011, Gemeindegründungsbewegungen. 2. Auflage, DiM, Schwelm. 